\title{
INFLUENCE OF ENVIRONMENTAL FACTORS ON HEIGHT AND WEIGHT OF SCHOOLCHILDREN
}

\author{
SONIA G. TOPP, B.Sc., Dip. Stat. \\ Assistant Lecturer \\ JUDITH COOK, M.A., M.B., B.Chir. \\ Assistant Lecturer \\ W. W. HOLLAND, M.D., B.Sc. \\ Professor \\ Department of Clinical Epidemiology and Social Medicine, St. Thomas's Hospital Medical School \\ AND \\ A. ELLIOTT, M.D., D.P.H. \\ County Medical Officer, Kent County Council
}

The growth of children is governed by their internal metabolic and hormonal state, which is in turn dependent on hereditary, environmental, nutritional and psychological factors and any severe illness they may experience. The attained height and weight of children are the product of the accumulated effects of these factors acting since conception, and any study of the reasons for differences in height and weight among children of the same age involves an examination of one or more of these factors.

Genetic differences in growth rate have been suggested by Jenss (1940), who found that, within groups matched for socio-economic background, children aged 6 to 8 years of American-born parents and ancestry showed a greater rate of weight gain than American children of the same age of Italian parents. In a comparison of Nilotic negroes and whites living in the Sudan, Roberts (1960) found that Nilotics had a considerably lower weight for height ratio at all ages and heights, though they were not undernourished. The same author previously examined statistics throughout the world, showing a close negative correlation between weight per unit stature at ages 6 to 14 years and average annual temperature (Roberts, 1953). The probable explanation given was that natural selection, acting over many generations, favours a slender physique in hotter climates, though other factors which vary between climatic regions, such as economic and nutritional conditions, may also be involved.

The relationship between the growth of children and their socio-economic background has been extensively studied. Bransby, Burn, Magee, and MacKecknie (1946) found, for example, that children from poor homes or large families were consistently smaller and lighter than those from good homes or smaller families. The authors' assessment of the children's homes was based on both the quality of care and economic conditions. Families were divided into three categories-good, fair and bad-accord-? ing to reports made by the children's schoolteachers. These reports were checked by a health visitor, and though both assessments are subjective, they are probably adequate in view of the broad scope of the inquiry. The findings of this study were confirmed by those of the Oxford Child Health Survey (Acheson and Hewitt, 1954), in which children of both sexes from the lower social class groups were found to be smaller than those of the same age from the higher social class groups. Other studies have been concerned with growth in relation to father's occupational status. Douglas and Blomfield (1958) found that the more skilled the father's occupation, the greater was the child's growth rate and stature. They also showed that children whose parents had risen in the social scale tended to be taller than those whose parents remained static, and that the children of parents who fell in the social scale were smaller than the average for their original social class group. In a study in Newcastle upon Tyne, Miller, Court, Walton, and Knox (1960) found that 3-year-old children of the professional and salaried classes were on average 2.5 $\mathrm{cm}$. taller and $0.5 \mathrm{~kg}$. heavier than those of semiskilled and unskilled workers.

The studies discussed above use very general 
measures of socio-economic conditions. Other investigations concerned with specific aspects of the child's environment draw similar conclusions. The heights and weights of Glasgow children have, for example, been shown to increase with the number of rooms in the home (Weir, 1952), and a group of boys who shared their beds have been found to have lower stature than a matched control group who slept one to a bed (Berry and Cowin, 1954). The latter study also demonstrated that grammar school boys were heavier than 'modern-school' boys of the same age and socio-economic group, that boys whose mothers worked were heavier than those whose mothers did not (a difference that may be explained by economic or emotional factors or a combination of both), and that children with few siblings were heavier and taller than those from large families. Yudkin (1944) and the Ministry of Health (1968) have also found height and weight to be inversely related to family size.

The relationship between growth rate and quality of nutrition has been established in a number of surveys. Howe and Schiller (1952) and Widdowson and McCance (1954) have, for example, studied children in Germany before and after the 1939-45 war. In the first study an examination of the heights and weights of schoolchildren for each of the years 1911 to 1952 showed a uniform increase in both measurements until the later years of the war, when the trend was sharply reversed. This reversal coincided with a great restriction in the children's food intake. The second study was based on an examination of the growth of children in two residential orphanages during the years 1947-48. Before the supplementation of their diets the heights and weights of the children were very much lower than average, but during supplementation their weight increased at a greater than normal rate.

An earlier study by Widdowson (1951) was designed to examine the effect of supplementation of diet on the growth of children. In a comparison between children from two orphanages the author found that, despite the fact that the diets of all children were supplemented, those supervised by a strict and unreasonable matron showed a slower rate of growth than those with a kindly matron. She concluded that psychological stresses due to harsh and unsympathetic handling may seriously curtail growth. The relationship between a child's growth rate and his emotional state has also been demonstrated by Acheson and Archer (1958), who showed that transfer to an orphanage was accompanied by retardation of growth, and by Patton and Gardner (1963), who found that, in a series of cases of maternal deprivation in the United States, the growth rates of psychologically deprived infants were severely retarded.

An association between retardation of growth and childhood illness has been demonstrated in the Oxford Child Health Survey (Hewitt, Westropp, and Acheson, 1955), in which children who had experienced severe illness between the ages of 1 and 5 years were found to have impaired rates of growth in height and skeletal maturity, and to be on average $1 \mathrm{~cm}$. shorter than those who had suffered no illness. This difference may be partially explained by the fact that severe illness in childhood is often associated with poor socio-economic conditions.

The above description gives a brief outline of the principal factors found to be associated with variation in growth between children of the same age. Most of the factors are, however, complex and closely inter-related, and therefore a more detailed examination of the independent effect of certain factors would be valuable. In addition, the investigations concerned with psychological and nutritional factors examined children in extreme conditions, and it would therefore be of interest to investigate the influence of these factors under more normal conditions. Lastly, the majority of studies discussed were undertaken some time ago, and socio-economic conditions have since changed.

The opportunity to study the effect of certain environmental factors on the growth of children in Great Britain today was provided by a recent examination of respiratory symptoms and ventilatory function among Kent schoolchildren (Holland, Halil, Bennett, and Elliott, 1969). This study included an assessment of the heights and weights of the children, which is directly related to the level of ventilatory function. In view of the absence of recent evidence on differences in height and weight among children in Great Britain, and the relevance of this subject to the establishment of standards of nutrition, the variations found in height and weight are here examined in greater detail.

It must be pointed out that it is very difficult to separate the influence of genetic and environmental factors on the height and weight of children.

Weight is less affected by genetic factors than height but weight is highly correlated with height. By using a weight for height index the influence of height on weight has been eliminated and the influence of genetic factors has been reduced as far as possible. In the interpretation of the results it cannot be concluded that the influence of environmental factors has been entirely separated from that of genetic factors. 


\section{Data Collection}

For the years 1964 and 1965 a special examination was introduced into the customary medical examination of all children resident and attending school in four areas of Kent (Holland et al., 1969). Data on each child's respiratory symptoms, illnesses since birth and the occupation of the father and mother were obtained from questionnaires completed by the parents. The medical examination included the measurement of height (in inches to the nearest half inch below) and weight (in pounds

TABLE I

MEAN WEIGHTS (lb.) ACCORDING TO SOCIAL CLASS

\begin{tabular}{|c|c|c|c|c|c|c|}
\hline \multirow{3}{*}{$\begin{array}{l}\text { Social } \\
\text { Class }\end{array}$} & \multicolumn{6}{|c|}{ Age/Sex } \\
\hline & \multicolumn{2}{|c|}{ 5-8 Years } & \multicolumn{2}{|c|}{ 19-13 Years } & \multicolumn{2}{|c|}{ 14-17 Years } \\
\hline & $\mathbf{M}$ & $\mathbf{F}$ & $\mathbf{M}$ & $\mathbf{F}$ & $\mathbf{M}$ & $\mathbf{F}$ \\
\hline $\begin{array}{l}\text { I-II } \\
\text { (A) }\end{array}$ & $\begin{array}{l}44 \cdot 73 \\
(515)\end{array}$ & $\begin{array}{l}42 \cdot 71 \\
(473)\end{array}$ & $\begin{array}{l}83 \cdot 35 \\
(271)\end{array}$ & $\begin{array}{l}88.46 \\
(274)\end{array}$ & $\begin{array}{c}114 \cdot 85 \\
(204)\end{array}$ & $\begin{array}{c}116 \cdot 27 \\
(228)\end{array}$ \\
\hline III & $\begin{array}{r}44.05 \\
(1261)\end{array}$ & $\begin{array}{r}42.65 \\
(1216)\end{array}$ & $\begin{array}{l}81 \cdot 87 \\
(826)\end{array}$ & $\begin{array}{l}87 \cdot 38 \\
(876)\end{array}$ & $\begin{array}{c}112 \cdot 23 \\
(754)\end{array}$ & $\begin{array}{c}113 \cdot 38 \\
(740)\end{array}$ \\
\hline $\begin{array}{l}\text { IV-V } \\
\text { (C) }\end{array}$ & $\begin{array}{l}43.08 \\
(495)\end{array}$ & $\begin{array}{l}42.54 \\
(446)\end{array}$ & $\begin{array}{l}83.05 \\
(387)\end{array}$ & $\begin{array}{l}85.45 \\
(413)\end{array}$ & $\begin{array}{c}108 \cdot 52 \\
(411)\end{array}$ & $\begin{array}{c}113 \cdot 13 \\
(371)\end{array}$ \\
\hline Total & $\begin{array}{r}43.99 \\
(2271)\end{array}$ & $\begin{array}{r}42 \cdot 64 \\
(2135)\end{array}$ & $\begin{array}{r}82.45 \\
(1484)\end{array}$ & $\begin{array}{r}87.06 \\
(1563)\end{array}$ & $\begin{array}{c}111 \cdot 51 \\
(1369)\end{array}$ & $\begin{array}{l}113.80 \\
(1339)\end{array}$ \\
\hline & A B C & A B C & A B C & A B C & A B C & A B C \\
\hline$\underset{\mathbf{B}}{\mathbf{A}}$ & $\begin{array}{l}12 \\
\quad 3\end{array}$ & $\overline{-}$ & $\begin{array}{c}-\overline{-} \\
P>0.0\end{array}$ & -1 & $\begin{array}{r}-2 \\
2\end{array}$ & $\overline{-}$ \\
\hline
\end{tabular}

(Sample sizes shown in brackets) to the nearest pound below). The examinations were performed by 12 medical officers, all of whom had been trained in a standardized method of examination. During the period of the survey each medical officer was visited on at least two occasions by a standard observer; their results were compared with his, and although some discrepancies were found, none of the differences shown in the study can be attributed to observer variability.

The mean heights and weights of children in each age/sex group have been calculated with respect to social class of the father (as defined by the Registrar General's classification of occupations), the number of hours for which the mother was employed (i.e., full-time, part-time, or non-employed) and the number of siblings.

\section{RESULTS}

Table I gives the mean weight of children in each age/sex group according to social class. As in later tables dealing with social class differences, classes I and II and IV and V have been combined.

Differences of high statistical significance are found among boys aged 5 years, the contrast being most significant between social class III and sociad $\vec{\varphi}$ classes IV and V; and among boys aged 14 years o⿺ more, whose mean weight is significantly lower iff. social classes IV and V than in social classes I and II. In each age/sex group the mean weight of children in social classes I and II is greater than in social class III; and, with the exception of 9 to 13-year-old boys, the mean weight of children in social class III is greater than those in social classes

TABLE II

MEAN WEIGHTS (lb.) ACCORDING TO NUMBER OF HOURS FOR WHICH MOTHER IS EMPLOYED

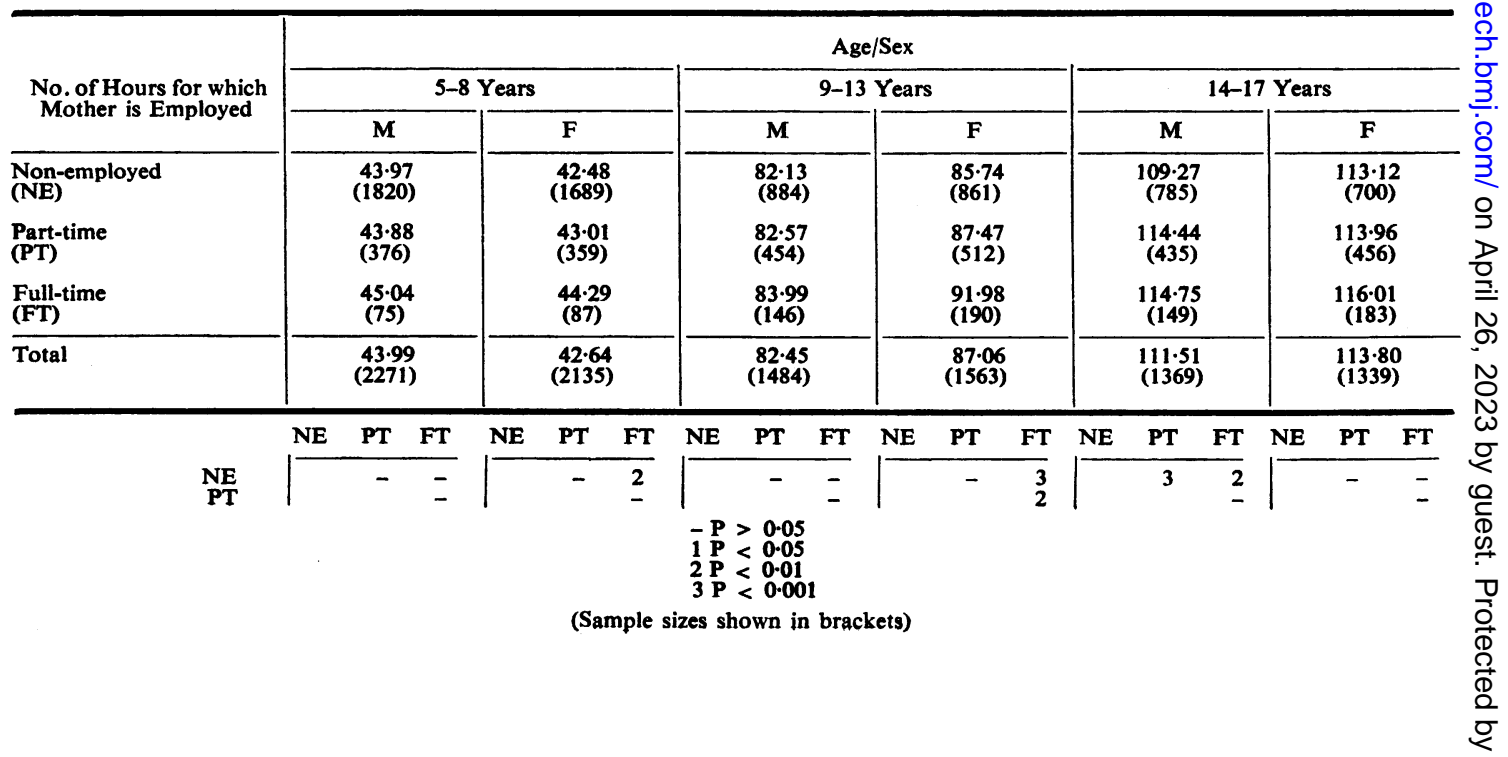


TABLE III

MEAN WEIGHTS (lb.) ACCORDING TO NUMBER OF SIBLINGS

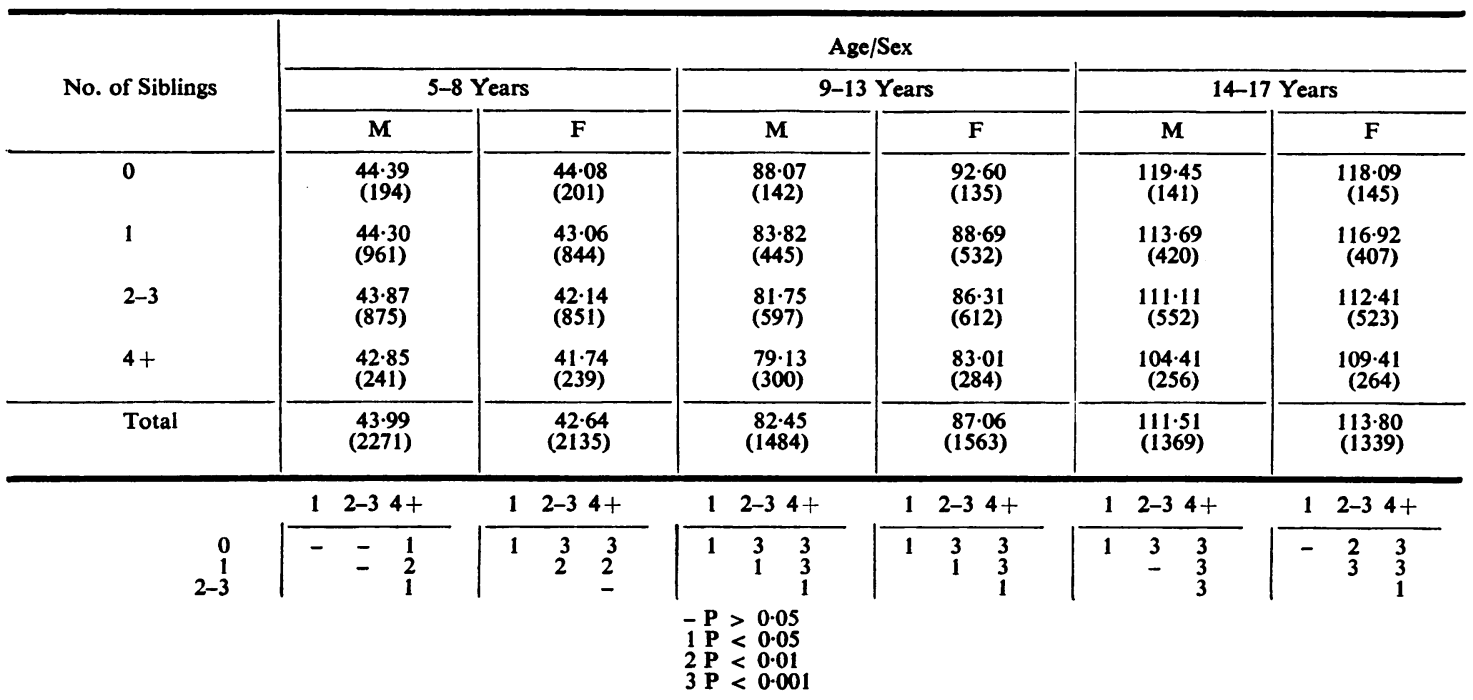

(Sample sizes shown in brackets)

IV and V. Some of these differences are small and are not statistically significant, but the consistency of the overall trend suggests that a social class gradient exists.

A comparison of the mean weights of children according to the number of hours for which the mother is employed demonstrates that mothers who work full-time have on average heavier children than those who work part-time, and that mothers who work part-time have heavier children than those who do not work (Table II). This finding is in agreement with that of Berry and Cowin (1954). In the two older groups differences in weight between children of mothers working full- or part-time are greater in girls than in boys.

An examination of weight in relation to the number of siblings shows that in all six age/sex groups children from large families tend to be lighter than those from small families, the absolute differences between groups being greater in the older children (Table III). In boys aged 5 to 8 years the differences are not statistically significant except for those with four or more siblings, who are lighter than the three other sibling groups. Again the consistency of the trend is evidence of an association between the two variables.

Social class, mother's employment and family size are found to influence the height of a child in a very similar way; differences in height are, however, considerably smaller than those of weight. Social class (Table IV) and family size (Table VI) appear to exert a greater influence on height than the number of hours for which the mother is employed (Table V). The effect of the last factor is not clearly defined, but, with the exception of 9 to

TABLE IV

MEAN HEIGHTS (INCHES) ACCORDING TO SOCIAL CLASS

\begin{tabular}{|c|c|c|c|c|c|c|}
\hline \multirow{3}{*}{$\begin{array}{l}\text { Social } \\
\text { Class }\end{array}$} & \multicolumn{6}{|c|}{ Age/Sex } \\
\hline & \multicolumn{2}{|c|}{ 5-8 Years } & \multicolumn{2}{|c|}{ 9-13 Years } & \multicolumn{2}{|c|}{ 14-17 Years } \\
\hline & $\mathbf{M}$ & $\mathbf{F}$ & $\mathbf{M}$ & $\mathbf{F}$ & $\mathbf{M}$ & $\mathbf{F}$ \\
\hline I-II & $43 \cdot 85$ & $43 \cdot 34$ & $57 \cdot 17$ & $58 \cdot 12$ & $63 \cdot 82$ & 63.04 \\
\hline III & $43 \cdot 64$ & $43 \cdot 27$ & $56 \cdot 76$ & $57 \cdot 82$ & $63 \cdot 31$ & $62 \cdot 33$ \\
\hline IV-V & $43 \cdot 14$ & 43.00 & $56 \cdot 48$ & $57 \cdot 42$ & $62 \cdot 47$ & 61.97 \\
\hline Total & $43 \cdot 58$ & $43 \cdot 23$ & $56 \cdot 76$ & $57 \cdot 77$ & $63 \cdot 13$ & $62 \cdot 35$ \\
\hline
\end{tabular}

TABLE V

MEAN HEIGHTS (INCHES) ACCORDING TO NUMBER OF HOURS FOR WHICH MOTHER IS EMPLOYED

\begin{tabular}{|c|c|c|c|c|c|c|}
\hline \multirow{3}{*}{$\begin{array}{l}\text { No. of } \\
\text { Hours for } \\
\text { which } \\
\text { Mother is } \\
\text { Employed }\end{array}$} & \multicolumn{6}{|c|}{ Age/Sex } \\
\hline & \multicolumn{2}{|c|}{ 5-8 Years } & \multicolumn{2}{|c|}{ 9-13 Years } & \multicolumn{2}{|c|}{ 14-17 Years } \\
\hline & $\mathbf{M}$ & $\mathbf{F}$ & $\mathbf{M}$ & $\mathbf{F}$ & $\mathbf{M}$ & $\mathbf{F}$ \\
\hline $\begin{array}{l}\text { Non- } \\
\text { employed } \\
\text { Part-time } \\
\text { Full-time }\end{array}$ & $\begin{array}{l}43.60 \\
43.47 \\
43.75\end{array}$ & $\begin{array}{l}43 \cdot 21 \\
43 \cdot 28 \\
43 \cdot 48\end{array}$ & $\begin{array}{l}56.81 \\
56.68 \\
56.73\end{array}$ & $\begin{array}{l}57.68 \\
57.79 \\
58.09\end{array}$ & $\begin{array}{l}62 \cdot 89 \\
63 \cdot 45 \\
63 \cdot 48\end{array}$ & $\begin{array}{l}\mathbf{6 2} \cdot 34 \\
62 \cdot 35 \\
62 \cdot 40\end{array}$ \\
\hline Total & $43 \cdot 58$ & $43 \cdot 23$ & $56 \cdot 76$ & $57 \cdot 77$ & $63 \cdot 13$ & $62 \cdot 35$ \\
\hline
\end{tabular}


TABLE VI

MEAN HEIGHTS (INCHES) ACCORDING TO NUMBER OF SIBLINGS

\begin{tabular}{|c|c|c|c|c|c|c|}
\hline \multirow{3}{*}{$\begin{array}{c}\text { No. of } \\
\text { Siblings }\end{array}$} & \multicolumn{6}{|c|}{ Age/Sex } \\
\hline & \multicolumn{2}{|c|}{ 5-8 Years } & \multicolumn{2}{|c|}{ 9-13 Years } & \multicolumn{2}{|c|}{ 14-17 Years } \\
\hline & $\mathbf{M}$ & $\mathbf{F}$ & $\mathbf{M}$ & $\mathbf{F}$ & $\mathbf{M}$ & $\mathbf{F}$ \\
\hline $\begin{array}{l}0 \\
1 \\
2-3 \\
4+\end{array}$ & $\begin{array}{l}43.86 \\
43.73 \\
43.51 \\
43.01\end{array}$ & $\begin{array}{l}43 \cdot 59 \\
43 \cdot 61 \\
42.94 \\
42 \cdot 59\end{array}$ & $\begin{array}{l}57 \cdot 34 \\
57 \cdot 16 \\
56 \cdot 61 \\
56 \cdot 21\end{array}$ & $\begin{array}{l}58 \cdot 24 \\
58 \cdot 29 \\
57.65 \\
56 \cdot 83\end{array}$ & $\begin{array}{l}63 \cdot 98 \\
63 \cdot 39 \\
63 \cdot 29 \\
61 \cdot 93\end{array}$ & $\begin{array}{l}63 \cdot 03 \\
62 \cdot 70 \\
62 \cdot 25 \\
61 \cdot 64\end{array}$ \\
\hline Total & $43 \cdot 58$ & $43 \cdot 23$ & $56 \cdot 76$ & $57 \cdot 77$ & $63 \cdot 13$ & $62 \cdot 35$ \\
\hline
\end{tabular}

13-year-old boys, children with full-time working mothers are still on average taller than those whose mothers work part-time or not at all.

It is here necessary to point out that the results given may be distorted for two reasons. First, the significance levels quoted in each table may be misleading, as the numbers of children examined for each factor are not proportional. This produces a non-orthogonal structure in the data, and the means given in each table may therefore be biased by the influence of the other environmental factors acting concurrently. Secondly, height is not a suitable measure for the influence of environmental factors since it is partially genetically determined. Although weight is less affected by genetic factors, it is highly correlated with height.

In order to eliminate the effect of height on weight, further analyses were made using an index of weight in relation to height. In a comparison of three such indices, Billewicz, Kemsley, and Thomson (1962) found that Quetelet's Index

$$
\frac{\text { (weight } \times 100 \text { ) }}{(\text { height })^{2}}
$$

was a suitable measure of weight for height, as it had a high correlation with weight and a low correlation with height. This index has the additional advantage of being sufficiently tractable for statistical analysis, that is, it retains an approximate normal distribution, which is necessary for manipulation of means and significance testing. These properties have been tested in a group of adult males and have been found to be very satisfactory (Khosla and Lowe, 1967). As Table VII demonstrates, Quetelet's Index appears to be a suitable measure of weight for height in children as well as adults, though its properties are more satisfactory for older children ( 9 to 17 years) than for young children (5 to 8 years). Among the two older age groups the index has a high correlation with weight, but in the youngest age group the correlation is lower. In all
TABLE VII

CORRELATIONS BETWEEN HEIGHT, WEIGHT AND QUETELET'S INDEX

\begin{tabular}{|c|c|c|c|c|c|c|}
\hline \multirow{3}{*}{ Correlation } & \multicolumn{6}{|c|}{ Age/Sex } \\
\hline & \multicolumn{2}{|c|}{ 5-8 Years } & \multicolumn{2}{|c|}{ 9-13 Years } & \multicolumn{2}{|c|}{ 14-17 Years } \\
\hline & $\mathbf{M}$ & $\mathbf{F}$ & $\mathbf{M}$ & $\mathbf{F}$ & $\mathbf{M}$ & $\mathbf{F}$ \\
\hline $\begin{array}{l}\mathrm{Ht}_{\mathrm{t}} \times \mathrm{Wt} \\
\mathrm{Ht} \times \text { Q.I. } \\
\text { Wt } \times \text { Q.I. }\end{array}$ & $\begin{array}{r}0.66 \\
-0.20 \\
0.58\end{array}$ & $\begin{array}{r}0.62 \\
-0.19 \\
0.62\end{array}$ & $\begin{array}{l}0.62 \\
0.09 \\
0.80\end{array}$ & $\begin{array}{l}0.66 \\
0.22 \\
0.87\end{array}$ & $\begin{array}{l}0.75 \\
0.24 \\
0.81\end{array}$ & $\begin{array}{l}0.52 \\
0.08 \\
0.87\end{array}$ \\
\hline Sample size & 2271 & 2135 & 1484 & 1563 & 1369 & 1339 \\
\hline
\end{tabular}

age/sex groups the index has a low correlation with height.

When the data are analysed using means of Quetelet's Index instead of means of weight, the influence of all environmental factors is altered and, in most cases, reduced. There is no consistent association between means of Quetelet's Index and social class (Table VIII). In three age/sex groups

TABLE VIII

MEANS OF QUETELET'S (lb. in.) INDEX ACCORDING TO SOCIAL CLASS

\begin{tabular}{|c|c|c|c|c|c|c|}
\hline \multirow{3}{*}{$\begin{array}{l}\text { Social } \\
\text { Class }\end{array}$} & \multicolumn{6}{|c|}{ Age/Sex } \\
\hline & \multicolumn{2}{|c|}{ 5-8 Years } & \multicolumn{2}{|c|}{ 9-13 Years } & \multicolumn{2}{|c|}{ 14-17 Years } \\
\hline & $\mathbf{M}$ & $\mathbf{F}$ & $\mathbf{M}$ & $\mathbf{F}$ & $\mathbf{M}$ & $\mathbf{F}$ \\
\hline I-II & $2 \cdot 32$ & $2 \cdot 27$ & $2 \cdot 54$ & $2 \cdot 60$ & $2 \cdot 80$ & 2.92 \\
\hline III & $2 \cdot 31$ & $2 \cdot 28$ & $2 \cdot 53$ & $2 \cdot 60$ & $2 \cdot 78$ & 2.91 \\
\hline $\begin{array}{l}\text { IV-V } \\
\text { (C) }\end{array}$ & $2 \cdot 31$ & $2 \cdot 30$ & $2 \cdot 59$ & $2 \cdot 57$ & $2 \cdot 76$ & 2.94 \\
\hline Total & $2 \cdot 31$ & $2 \cdot 28$ & $2 \cdot 55$ & $2 \cdot 59$ & $2 \cdot 78$ & $2 \cdot 92$ \\
\hline & A B C & A B C & A B C & A B C & A B C & A B C \\
\hline $\begin{array}{l}\mathbf{A} \\
\mathbf{B}\end{array}$ & - & - & $-\overline{1}$ & - & 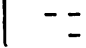 & - \\
\hline
\end{tabular}

children of lower social class parents (IV and V) appear to be heavier for their height than children of high social class parents (I and II) and there is no consistent trend within age or sex groups. In addition, only one difference (between 9 to 13-yearold boys of social class III and those of social classes IV and V) is significant at the $5 \%$ level. A similar trend remains for children whose mothers work full-time, part-time or not at all, but the differences between means are smaller and less significant when Quetelet's Index is used (Table IX). There is no evidence of consistent family-size differences among 5 to 8-year-old children, though in the two older age groups children of both sexes appear heavier in small families (Table X). A closer exami- 
nation of the data shows this to be true within each social class.

Because of the non-orthogonality of the data, $t$ tests on the means do not adequately reveal differences between groups as the means may be distorted by interaction effects. The means of Quetelet's Index have therefore been analysed by a method of 'fitting constants' (Stevens, 1948), which takes into account the variation in numbers of subjects in each group and provides a numerical estimate of the effect of each individual factor, testing the differences between groups for each variable in turn. The first-order interactions between the three variables are also analysed. The results of the significance tests using this method are given in Table XI.

The differences between social classes in means of Quetelet's Index are significant only in 9 to 13year-old boys, and this is due to the low mean in social class III. Highly significant differences in means between groups with mothers working fulltime, part-time or not at all are found in 9 to 13year-old girls and 14 to 17 -year-old boys, and significant differences at the $5 \%$ level are found in 5 to 8-year-old girls. The differences in the other three age/sex groups are directionally consistent with the differences found in the first groups but are not significant at the $5 \%$ level. When the two older groups are analysed according to family size, highly significant differences are found for both sexes. Although family size differences are not statistically significant among 5 to 8-year-olds, they are again consistent with the differences in the two older age groups. First-order interactions are statistically significant in three groups but are not consistent in all age/sex groups. Significant interactions of Quetelet's Index between social class and number of siblings are found among boys from the two older age groups, but not among girls.

TABLE IX

MEANS OF QUETELET'S INDEX (lb. in.) ACCORDING TO NUMBER OF HOURS FOR WHICH MOTHER IS EMPLOYED

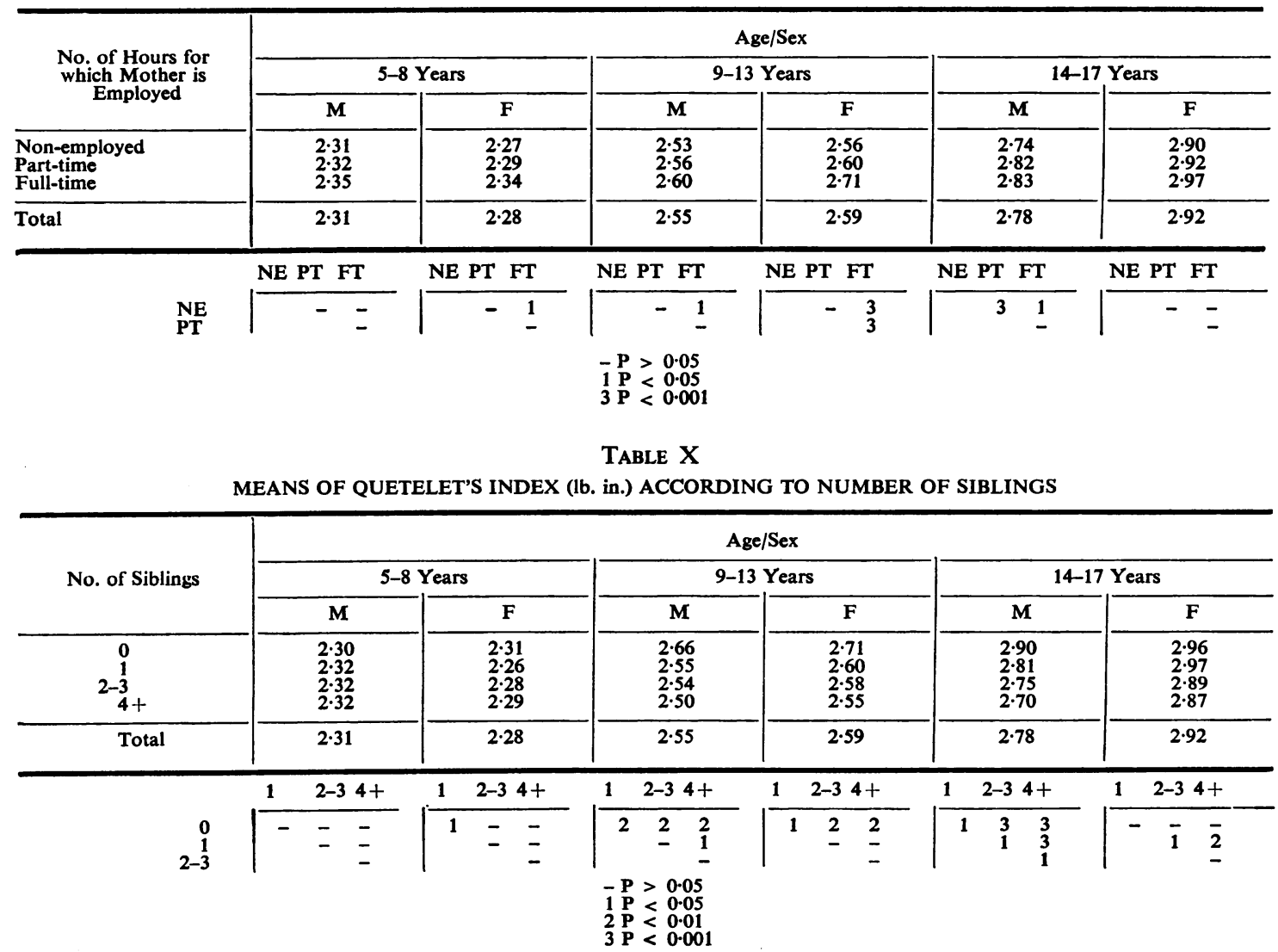


TABLE XI

SIGNIFICANCE OF MAIN AND FIRST-ORDER EFFECTS

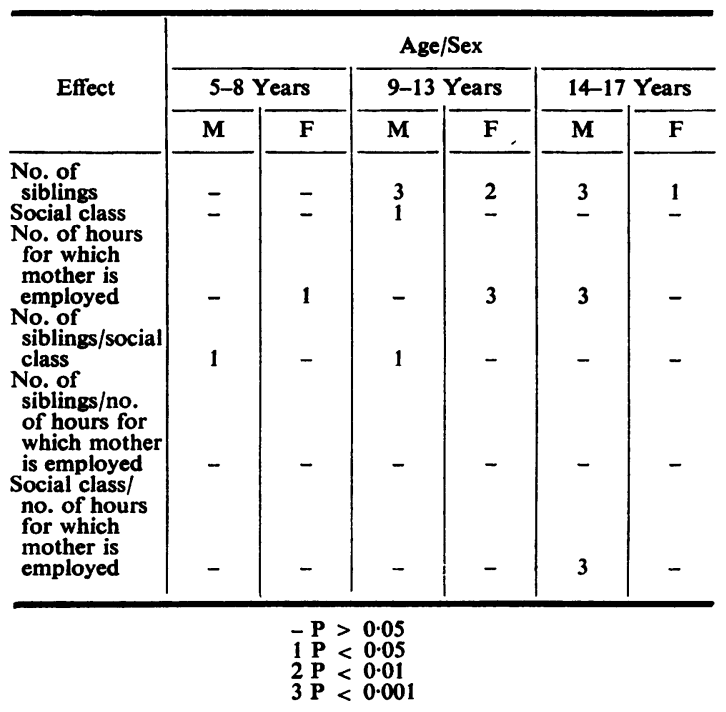

\section{Discussion}

The preliminary analysis of the data shows that all three of the environmental factors examined influence the weight of children. However, weight is to some extent dependent on height, and height is partially determined by genetic factors. A reliable index of weight for height is therefore required to eliminate the effect of height and reduce distortion of results by genetic influences. Quetelet's Index

$$
\frac{(\text { weight } \times 100)}{{\text { (height })^{2}}^{2}}
$$

has been found to be a suitable measure of weight for height (Khosla and Lowe, 1967; Billewicz et al., 1962) and also has the advantage that it is based on readily obtainable body measurements. It must, however, be remembered that the use of this index may not eliminate the influence of genetic factors. The index takes no account of variations in muscularity, body fat or underlying bony structure, and the possibility therefore remains that the index may simply reveal differences in body type, which is itself genetically determined.

Analyses using Quetelet's Index show that the preliminary analysis may have been misleading. The influence of social class is no longer apparent, and the differences originally found between social class groups may therefore be attributed to differences in height and not to differences in body fat or body type. The association remains for the number of hours for which the mother is employed (in three age groups) and for the number of siblings (in two older age groups). The influence of the last factor is greater than the first.

These differences are not attributable to differences in the age distribution (Table XII). There are no significant differences in age distribution by environmental factors within 5 to 8-year-olds or 9 to 13 year-olds of either sex. However, in the oldest age group, there are significant differences in age distribution in social class and number of siblings in males, and social class and number of hours for which the mother is employed in females. As social class was not found to have a significant effect on the weight for height of children, this age difference may not be used to explain the final results. The association of age with the number of siblings is small in males, and is not found in females. It therefore appears that few of the differences in weight for height may be explained by age differences. Differences in weight for height according to the number of hours for which the mother is employed were found only for males, for whom there are no significant age differences. It therefore seems that although some differences in age distribution are present, they are small and do not influence the final results.

It is, however, impossible to assume that the $\varnothing \overrightarrow{0}$ differences found in weight for height are due solely to environmental influences, since the index mayco have revealed differences in body type, which is $?$ genetically determined, or in body fat or other soft tissues.

The influence of both the number of siblings and the number of hours for which the mother is employed appears to increase with age; differences found among 5-year-olds are smaller than those for the two older age groups and the largest differences occur among 14-year-olds. There are several possible explanations for this. Firstly, retardation of growth caused by deficiency in nutrition is more likely to be evident at the time of the adolescent growth spurt. Secondly, Quetelet's Index was found to be a less adequate measure of weight for height in 5 to 8year-olds than in older children, and this inadequacy may have biased the results. Lastly, 14 to 17 year-olds are more likely to be members of a 'completed' family than are 5 to 8-year-olds. It has been shown that the advent of additional children in a family acts as a check on the growth of all preceding siblings, and thus birth rank position will determine the influence of the presence of other siblings on the growth of a child (Grant, 1964).

\section{SUMMARY}

An earlier investigation of the effects of environmental and personal factors on respiratory symp- 
TABLE XII

PERCENTAGE DISTRIBUTION OF AGE ACCORDING TO SOCIAL CLASS, NUMBER OF HOURS FOR WHICH MOTHER IS EMPLOYED, AND NUMBER OF SIBLINGS

\begin{tabular}{c|ccc|}
\hline & \multicolumn{3}{|c|}{ Social Class } \\
$\begin{array}{c}\text { Age } \\
\text { (yr) }\end{array}$ & I-II & III & IV-V \\
\hline & & & \\
\hline 5 & 62.9 & $65 \cdot 1$ & $61 \cdot 8$ \\
6 & $35 \cdot 9$ & $33 \cdot 6$ & $37 \cdot 2$ \\
7 & $1 \cdot 2$ & $1 \cdot 3$ & $1 \cdot 0$ \\
\hline 8 & 0 & 0 & 0 \\
\hline Total & $100 \%$ & $100 \%$ & $100 \%$ \\
\hline Sample size & $(515)$ & $(1261)$ & $(495)$ \\
\hline & & $x^{2}=2 \cdot 6$ \\
\hline
\end{tabular}

\begin{tabular}{|c|c|c|c|c|c|}
\hline No. of & $\begin{array}{l}\text { for } \\
\text { Empl }\end{array}$ & Mother & & lings & \\
\hline $\mathrm{NE}$ & PT & FT & 0 & $2-3$ & $4+$ \\
\hline
\end{tabular}

Total

(a) Males aged 5 to 8 years

\begin{tabular}{c|ccc|}
\hline 5 & $64 \cdot 1$ & $63 \cdot 6$ & $64 \cdot 3$ \\
6 & $33 \cdot 4$ & $35 \cdot 0$ & $33 \cdot 4$ \\
7 & $2 \cdot 5$ & $1 \cdot 4$ & $2 \cdot 3$ \\
8 & 0 & 0 & 0 \\
\hline Total & $100 \%$ & $100 \%$ & $100 \%$ \\
\hline Sample size & $(473)$ & $(1216)$ & $(446)$ \\
\hline & & \\
\hline
\end{tabular}

\begin{tabular}{|c|c|c|}
\hline $\begin{array}{c}63.8 \\
34.9 \\
1.3 \\
0\end{array}$ & $\begin{array}{c}65.4 \\
33.8 \\
0.8 \\
0\end{array}$ & $\begin{array}{c}58 \cdot 7 \\
40 \cdot 0 \\
1.3 \\
0\end{array}$ \\
\hline $100 \%$ & $100 \%$ & $100 \%$ \\
\hline (1820) & (376) & (75) \\
\hline \multicolumn{3}{|c|}{$x^{2}=1.8$} \\
\hline
\end{tabular}

\begin{tabular}{|cccc|}
\hline $\begin{array}{c}66.0 \\
32.5\end{array}$ & $\begin{array}{c}65.4 \\
33.9\end{array}$ & $\begin{array}{c}63.4 \\
34.8\end{array}$ & $\begin{array}{r}58.1 \\
1.5\end{array}$ \\
0 & 0.7 & 1.8 & 0.8 \\
0 & 0 & 0 \\
\hline $100 \%$ & $100 \%$ & $100 \%$ & $100 \%$ \\
\hline$(194)$ & $(961)$ & $(875)$ & $(241)$ \\
\hline \multicolumn{5}{c}{$\chi^{2}=10.0$} \\
\end{tabular}

(b) Females aged 5 to 8 years

\begin{tabular}{|c|c|c|c|c|c|c|c|}
\hline $\begin{array}{c}63.6 \\
34.5 \\
1.9 \\
0\end{array}$ & $\begin{array}{c}64 \cdot 4 \\
34 \cdot 5 \\
1 \cdot 1 \\
0\end{array}$ & $\begin{array}{c}65 \cdot 5 \\
31 \cdot 0 \\
3 \cdot 5 \\
0\end{array}$ & $\begin{array}{c}67 \cdot 2 \\
31 \cdot 3 \\
1 \cdot 5 \\
0\end{array}$ & $\begin{array}{c}63 \cdot 6 \\
35 \cdot 1 \\
1.3 \\
0\end{array}$ & $\begin{array}{c}63 \cdot 6 \\
34 \cdot 3 \\
2 \cdot 1 \\
0\end{array}$ & $\begin{array}{c}62 \cdot 8 \\
34 \cdot 3 \\
2 \cdot 9 \\
0\end{array}$ & $\begin{array}{c}63.9 \\
34.3 \\
1.8 \\
0\end{array}$ \\
\hline $100 \%$ & $100 \%$ & $100 \%$ & $100 \%$ & $100 \%$ & $100 \%$ & $100 \%$ & $100 \%$ \\
\hline (1689) & (359) & (87) & (201) & (844) & (851) & (239) & (2135) \\
\hline \multicolumn{3}{|c|}{$x^{2}=2.6$} & \multicolumn{4}{|c|}{$x^{2}=4.4$} & \\
\hline
\end{tabular}

(c) Males aged 9 to 13 years

\begin{tabular}{c|ccc|}
\hline 9 & 0 & 0 & 0 \\
10 & $0 \cdot 4$ & $0 \cdot 0$ & $0 \cdot 3$ \\
11 & $63 \cdot 1$ & $64 \cdot 2$ & $66 \cdot 9$ \\
12 & $34 \cdot 3$ & $33 \cdot 3$ & $3 \cdot 0$ \\
13 & $2 \cdot 2$ & $2 \cdot 5$ & $1 \cdot 8$ \\
\hline Total & $100 \%$ & $100 \%$ & $100 \%$ \\
\hline Sample size & $(271)$ & $(826)$ & $(387)$ \\
\hline & & \\
\hline
\end{tabular}

\begin{tabular}{ccc|}
\hline 0 & 0 & 0 \\
0.1 & 0.2 & 0.0 \\
$64 \cdot 3$ & 65.4 & 65.1 \\
32.8 & 32.8 & 33.6 \\
2.8 & 1.6 & 1.3 \\
\hline $100 \%$ & $100 \%$ & $100 \%$ \\
\hline$(884)$ & $(454)$ & $(146)$ \\
\hline & $x^{2}=2.9$ & \\
\hline
\end{tabular}

\begin{tabular}{|cccc|}
\hline 0 & 0 & 0 & 0 \\
0.0 & 0.2 & 0.2 & 0.0 \\
59.2 & 67.6 & 63.6 & 65.0 \\
39.4 & 30.8 & 34.0 & 30.7 \\
1.4 & 1.4 & 2.2 & 4.3 \\
\hline $100 \%$ & $100 \%$ & $100 \%$ & $100 \%$ \\
\hline$(142)$ & $(445)$ & $(597)$ & $(300)$ \\
\hline \multicolumn{5}{c}{} \\
\hline
\end{tabular}

$\begin{array}{r}0 \\ 0 \cdot 1 \\ 64 \cdot 7 \\ 32.9 \\ 2 \cdot 3 \\ \hline 100 \% \\ \hline(1484) \\ \hline\end{array}$

(d) Females aged 9 to 13 years

\begin{tabular}{c|ccc|}
\hline 9 & 0 & 0 & 0 \\
10 & 0.4 & 0.0 & 0.0 \\
11 & $59 \cdot 8$ & 54.2 & 58.1 \\
12 & 35.8 & 39.7 & 37.5 \\
13 & 4.0 & 6.1 & 4.4 \\
\hline Total & $100 \%$ & $100 \%$ & $100 \%$ \\
\hline Sample size & $(274)$ & $(870)$ & $(413)$ \\
\hline & & \\
\hline
\end{tabular}

\begin{tabular}{ccc|}
\hline 0 & 0 & 0 \\
0.1 & 0.0 & 0.0 \\
56.6 & 57.4 & 51.6 \\
38.1 & 37.3 & 43.2 \\
5.2 & 5.3 & 5.3 \\
\hline $100 \%$ & $100 \%$ & $100 \%$ \\
\hline$(861)$ & $(512)$ & $(190)$ \\
\hline & $x^{2}=2.2$ \\
\hline
\end{tabular}

\begin{tabular}{|cccc|}
\hline 0 & 0 & 0 & 0 \\
0.0 & 0.2 & 0.0 & 0.0 \\
55.3 & 55.5 & 56.9 & 54.9 \\
34.8 & 39.8 & 37.2 & 40.1 \\
5.9 & 4.7 & 5.7 & 4.9 \\
\hline $100 \%$ & $100 \%$ & $100 \%$ & $100 \%$ \\
\hline$(135)$ & $(532)$ & $(612)$ & $(284)$ \\
\hline \multicolumn{5}{c}{} \\
\hline \multicolumn{4}{c}{$\chi^{2}=2.3$} \\
\hline
\end{tabular}

\begin{tabular}{c}
\hline 0 \\
$0 \cdot 1$ \\
$56 \cdot 2$ \\
$38 \cdot 5$ \\
$5 \cdot 2$ \\
\hline $100 \%$ \\
\hline$(1563)$ \\
\hline
\end{tabular}

(e) Males aged 14 to 17 years

\begin{tabular}{c|ccc|}
\hline 14 & 50.5 & 61.4 & 68.1 \\
15 & 40.7 & 34.6 & 28.7 \\
16 & 8.8 & 4.0 & 3.2 \\
17 & 0 & 0 & 0 \\
\hline Total & $100 \%$ & $100 \%$ & $100 \%$ \\
\hline Sample size & $(204)$ & $(754)$ & $(411)$ \\
\hline & & \\
\hline
\end{tabular}

\begin{tabular}{|c|c|c|}
\hline $\begin{array}{c}59 \cdot 6 \\
35.9 \\
4.5 \\
0\end{array}$ & $\begin{array}{c}67.4 \\
28.7 \\
3.9 \\
0\end{array}$ & $\begin{array}{c}57 \cdot 0 \\
36 \cdot 9 \\
6 \cdot 1 \\
0\end{array}$ \\
\hline $100 \%$ & $100 \%$ & $100 \%$ \\
\hline (785) & (435) & (149) \\
\hline \multicolumn{3}{|c|}{$x^{2}=9 \cdot 2$} \\
\hline
\end{tabular}

\begin{tabular}{cccc}
\hline $\begin{array}{c}58 \cdot 1 \\
34.8\end{array}$ & $59 \cdot 8$ & 61.4 & 68.0 \\
7.1 & 5.0 & 33.7 & 31.2 \\
0 & 0 & 4.9 & 0.8 \\
\hline $100 \%$ & $100 \%$ & $100 \%$ & $100 \%$ \\
\hline$(141)$ & $(420)$ & $(552)$ & $(256)$ \\
\hline \multicolumn{5}{c}{$\chi^{2}=13.7$} \\
\hline
\end{tabular}

\begin{tabular}{c}
\hline $\begin{array}{c}61 \cdot 8 \\
33 \cdot 7 \\
4 \cdot 5 \\
0\end{array}$ \\
\hline $100 \%$ \\
\hline$(1369)$ \\
\hline
\end{tabular}

(f) Females aged 14 to 17 years

\begin{tabular}{|c|c|c|c|c|c|c|c|c|c|c|c|}
\hline $\begin{array}{l}14 \\
15 \\
16 \\
17\end{array}$ & $\begin{array}{c}43.0 \\
41.7 \\
15.3 \\
0\end{array}$ & $\begin{array}{c}56 \cdot 6 \\
36.4 \\
7.0 \\
0\end{array}$ & $\begin{array}{c}60.6 \\
33.7 \\
5.7 \\
0\end{array}$ & $\begin{array}{c}54 \cdot 3 \\
36 \cdot 7 \\
9 \cdot 0 \\
0\end{array}$ & $\begin{array}{c}61 \cdot 0 \\
32.9 \\
6.1 \\
0\end{array}$ & $\begin{array}{l}45.9 \\
44.8 \\
9.3 \\
0\end{array}$ & $\begin{array}{c}47 \cdot 6 \\
42 \cdot 1 \\
10 \cdot 3 \\
0\end{array}$ & $\begin{array}{c}54 \cdot 5 \\
36.4 \\
9.1 \\
0\end{array}$ & $\begin{array}{c}57.0 \\
35.2 \\
7.8 \\
0\end{array}$ & $\begin{array}{c}58 \cdot 0 \\
36.4 \\
5.6 \\
0\end{array}$ & $\begin{array}{c}55 \cdot 4 \\
36 \cdot 5 \\
8 \cdot 1 \\
0\end{array}$ \\
\hline Total & $100 \%$ & $100 \%$ & $100 \%$ & $100 \%$ & $100 \%$ & $100 \%$ & $100 \%$ & $100 \%$ & $100 \%$ & $100 \%$ & $100 \%$ \\
\hline \multirow[t]{2}{*}{ Sample size } & (228) & $(740)$ & (371) & $(700)$ & (456) & (183) & $(145)$ & (407) & (523) & (264) & (1339) \\
\hline & \multicolumn{3}{|c|}{$x^{2}=29.5$} & \multicolumn{3}{|c|}{$x^{2}=14.0$} & \multicolumn{4}{|c|}{$x^{2}=8.4$} & \\
\hline
\end{tabular}


toms and ventilatory function among 10,971 schoolchildren (Holland et al., 1969) provided the data for the present study of the influence of certain environmental factors on the heights and weights of children. Three factors were examined-social class, number of siblings and the number of hours for which the mother was employed (i.e., full-time, part-time or non-employed). The effects of these factors on both height and weight were calculated. In order to eliminate the influence of height (which is partially determined by genetic factors) on weight, further analyses were done using Quetelet's Index

$$
\frac{(\text { weight } \times 100)}{(\text { height })^{2}}
$$

as a measurement of weight for height.

Weight was found to be associated with all three factors for both sexes and in each age group5 to 8,9 to 13 , and 14 to 17 years. No association was found between weight for height and social class, but weight for height was found to be associated with the number of siblings and the number of hours for which the mother was employed, the degree of association being greater for the number of siblings. The influence of both factors was found to be greater in the two older age groups than in the youngest one.

This work was supported in part by a grant from the Department of Health and Social Security. The investigation has been made possible by the support and help of many people, in particular the staffs of the Kent County Council in the health and teaching services. The medical and health visiting staffs have devoted considerable time and energy to this project. Our thanks are also due to Mr. S. G. Nicholas for the preparation of punched cards. The results were analysed at the Imperial College Centre for Computing and Automation.

\section{REFERENCES}

ACHESON, R. M., and ARCHER, M. (1958). Studies of growth of children living in residential institutions. 1 Admission, read before the Society for Social Medicine in Dublin, 1958. See also Brit. med. J., 2, 911.

and HEWITT, D. (1954). Oxford Child Health Survey: stature and skeletal maturation in the preschool child. Brit. J. prev. soc. Med., 8, 59.

BERRY, W. T. C., and COWIN, P. J. (1954). Conditions associated with growth of boys, 1950-1. Brit. med. J., 1, 847.

BILLEWICZ, W. Z., KEMSLEY, W. F. F., and THOMSON, A. M. (1962). Indices of adiposity. Brit. J. prev. soc. Med., 16, 183.
BRANSBY, E. R., BURN, J. L., MAGEE, H. E., and MACKECKNIE, D. M. (1946). Effect of certain social conditions on the health of school-children. Brit. med. J., 2, 767.

DOUGLAS, J. W. B., and BLOMFIELD, J. M. (1958). Children under Five. Allen and Unwin, London.

GRANT, M. W. (1964). Rate of growth in relation to birth rank and family size. Brit. J. prev. soc. Med., $18,35$.

HEWITT, D., WESTROPP, C. K., and ACHESON, R. M. (1955). Oxford Child Health Survey. Effect of childish ailments on skeletal development. Brit. $J$. prev. soc. Med., 9, 179.

HOLLAND, W. W., HALIL, T., BENNETT, A. E., and ELLIOTT, A. (1969). Factors influencing the onset of chronic respiratory disease. Brit. med. J., 2, 205.

HOWE, P. E., and SCHILLER, M. (1952). Growth responses of the school child to changes in diet and environmental factors. J. appl.Physiol., 5, 51 .

JENSS, R. M. (1940). Gain in weight and its association with ancestry and economic status. Hum. Biol., 12, 532.

KHOSLA, T., and LOWE, C. R. (1967). Indices of obesity derived from body weight and height. Brit. J. prev. soc. Med., 21, 122.

MILLER, F. J. W., COURT, S. D. M., WALTON, W. S., and KNOX, E. G. (1960). Growing up in Newcastle upon Tyne. A Continuous Study of Health and Illness in Young Children within their families. Oxford University Press, London.

MINISTRY OF HEALTH (1968). A Pilot Survey of the Nutrition of Young Children in 1963.

Reports on Public Health and Medical Subjects, No표 118. H.M.S.O., London.

PATTON, R. G., and GARDNER, L. I. (1963). Growth Failure in Maternal Deprivation (A Collection of Case Histories and Discussion). Thomas, Springfield, Illinois, U.S.A.

ROBERTS, D. F. (1953). Body weight, race and climate. Amer. J. phys. Anthrop., N.S., 11, 533.

(1960). Effects of race and climate on human growth as exemplified by studies on African children. In Human Growth, edited by Tanner, J. M., p. 59. Symposia of the Society for the Study of Human Biology, Vol. 3, Pergamon Press, Oxford.

STEVENS, W. L. (1948). Statistical analysis of a nonorthogonal tri-factorial experiment. Biometrika, 35, 346.

WEIR, J. B. DE V. (1952). The assessment of growth of schoolchildren with special reference to secular changes. Brit. J. Nutr., 6, 19.

WIDDOWSON, E. M. (1951). Mental contentment and physical growth. Lancet, 1, 1316.

and MCCANCE, R. A. (1954). Studies on the nutritive value of bread and on the effect of variations in the extraction rate of flour on the growth of undernourished children. Spec. Rep. Ser. med. Res. Coun. (Lond.), No. 287.

YUDKIN, J. (1944). Nutrition and size of family. Lancet, 2, 384. 